\title{
MICRO- AND MACROELEMENTS CONTENT IN RATS' LIVER AND KIDNEYS AFTER EXPOSURE TO CADMIUM SULFIDE NANOPARTICLES AND CADMIUM CHLORIDE
} Apykhtina O. L., Kozlov K. P.

\section{State Institution «Institute for Occupational Health of the National Academy of Medical Sciences of Ukraine», Kyiv}

Introduction. The introduction of cadmium nanoparticles (NP) in production makes it necessary to study the mechanism of their action both at the cellular level and at the level of organs and systems, to determine biomarkers of their effects, especially as comparing to their ionic forms.

The aim of the study was - to compare the content of micro and macro elements in the liver and kidneys of experimental animals after exposure to cadmium sulfide NP and cadmium chloride.

Materials and methods. The study was conducted on mature male Wistar rats 160-180 g, intraperitoneally injected with CdS NP of 4-6 nm of 9-11 nm size as well as $\mathrm{CdCl}_{2}$ in $0,08 \mathrm{mg} / \mathrm{kg} /$ day dose adjusted to cadmium. Toxic effects were evaluated after 30 injections ( 1,5 months), 60 injections ( 3,0 months) and in the post-exposure period (1,5 months after cessation of the exposure).

Results. In the liver of experimental animals the most intensive accumulation of cadmium was observed after exposure to $\mathrm{CdCl}_{2}$, especially in the post-exposure period. There was a higher content of cadmium after exposure to CdS NP-6 nm, as compare to CdS NP 9-11 nm. Along with the increase in the cadmium content in the liver, the growth of the content of copper, iron (more intensively with $\mathrm{CdCl}_{2}$ ), iron, and lower selenium levels were recorded (especially for CdS NP 4-6 nm). Significant accumulation of cadmium was recorded in the kidneys, especially in the post-exposure period, which can indicate an intensive elimination from the body. A significant accumulation of cadmium was recorded in the kidneys, especially in the post-exposure period, which can point to an intensive elimination from the body. The prolonged exposure to cadmium compounds also led to the increase of copper levels and decrease in iron and selenium levels in the kidneys. The most significant changes were recorded after exposure to CdS NP, especially of 4-6 nm size, as compared to $\mathrm{CdCl}_{2}$. The intensive accumulation of cadmium and imbalance of trace elements can play a leading role in hepatotoxic and nephrotoxic effects of cadmium compounds in nano- and ionic form.

Conclusions. Determination of the content of cadmium, macro- and microelements in the inner organs allows assessing cadmium toxicokinetics in the body, predicting the pathogenetic features of its toxic effects, especially in the post-exposure period, as well as studying the peculiarities of the pathogenesis of its organotoxic action.

Key words: Cadmium, Nanoparticles, Liver, Kidneys, Zinc, Selenium, Copper, Iron, Calcium

\section{Introduction}

Intensive development of nanotechnologies contributes to application of nanoparticles (NP) in various industries. Cadmium nanomaterials are widely used in optical and electronic devices in the manufacture of solar cells, photo diodes and light diodes; quantum dots based on cadmium compounds can be used as biological markers [1, 2]. Introduction of cadmium $\mathrm{NP}$ in production makes it necessary to study the mechanism of their action both at the cellular level and at the level of organs and systems, to determine biomarkers of their effects, especially as compared to their ionic form.

Cadmium and its compounds are global environmental pollutants. In case of excessive ingestion cadmium causes damages in kidneys, liver, reproductive organs, immune, bone and nervous systems [3-5].
In general, cadmium compounds are highly toxic substances, characterized by mutagenic and genotoxic effects and high cumulative properties, demonstrating carcinogenic effects [6-8].

Cadmium toxicokinetics is characterized by some features that determine its high cumulative properties and toxic effects. The liver and kidneys play a leading role in accumulation and redistribution of cadmium in the body. With the inhalation of cadmium compounds, about $40-60 \%$ of cadmium enters the bloodstream, with oral intake this proportion is much smaller and is $5-10 \%$. In the blood cadmium is accumulated mainly in erythrocytes, to a lesser extent in leukocytes, only a small percentage (up to $10 \%$ ) remains in plasma. Almost all cadmium presented in the plasma binds metallothioneins, proteins or low molecular weight thiol compounds, glutathione or 
cysteine, in particular [9]. With inhalation cadmium enters the bloodstream. After oral absorption, cadmium is first transported through the portal vein to the liver, and then accumulates in hepatocytes, where it induces the synthesis of metallothioneins. Cadmium is associated with high affinity to these low molecular compounds; thus cadmium becomes isolated and its toxicity to cells is eliminated. Complexes of metallothionein-cadmium from hepatocytes release into the blood as a result of natural excretion or cell death.

After intake with blood in the internal organs, cadmium can be released from protein complexes and binds with other target molecules on the cell surface or enter the cell by means of metal ions transporters [10]. Complexes between cadmium and low molecular weight proteins are filtered by the renal glomeruli and in the proximal tubules are captured by epithelial cells. At early stages of cadmium exposure only very small amounts of these complexes are excreted with urine. With increasing the cadmium content in proximal tubules due to the cytotoxic action, epithelial cells are being damaged, causing disorders in the processes of reabsorption, and the concentration of cadmium and low molecular weight proteins in the urine increases [11].

Estimation of cadmium accumulation in inner organs of rats after exposure to cadmium NP and cadmium chloride makes it possible to analyze the peculiarities of its distribution in the body, the degree of intoxication, while the analysis of micro- and macroelements' content, also, allows evaluating the peculiarities of intoxication pathogenesis and mechanisms of intoxication development.

The aim of the study was to compare the content of micro and macro elements in the liver and kidneys of experimental animals after exposure to cadmium sulfide NP of different size, and cadmium chloride.

\section{Materials and methods}

We used cadmium sulphide compounds in the nanoform (CdS NP) with the average dimensions of 4$6 \mathrm{~nm}$ and $9-11 \mathrm{~nm}$, as well as cadmium in ionic form, represented by cadmium chloride $\left(\mathrm{CdCl}_{2}\right)$, soluble in water. Cadmium sulfide NP were prepared by chemical synthesis, using a sodium polyphosphate $\left(\mathrm{NaPO}_{3}\right)$ $\mathrm{n}$ stabilizer. The dimensions of NP were determined by electronic microscopy.

The study was conducted on mature male Wistar rats $160-180 \mathrm{~g}$. The animals were kept in vivarium on a standardized diet with free access to drinking water. There were three experimental groups and the control group. The first experimental group was injected with CdS NP of 4-6 nm size, the second - with CdS NP of 9-11 nm size, the third - with $\mathrm{CdCl}_{2}$. The control group received a physiological solution. These substances were administered intraperitoneally daily 5 times a week (simulation of a working week) in $0,08 \mathrm{mg} / \mathrm{kg} /$ day dose adjusted to cadmium. Toxic effects were evaluated after 30 injections (1,5 months), 60 injections (3,0 months) and in the post-exposure period ( 1,5 months after cessation of the exposure). At the end of the experiment the animals were sacrificed by decapitation and the internal organs for investigation were removed. All manipulations with animals were carried out in accordance with the provisions of the European Convention on Protection of Vertebrate Animals, used for Experimental and Other Scientific Purposes (Strasbourg, 1985).

Macro- and microelement content was measured by X-ray fluorescence spectroscopy (Elvax CEP-01 $\mathrm{X}$-ray fluorescence spectrometer). The advantage of the method is in the minimum sample preparation, when organs were dried to a constant mass, followed by compression into tablets. Simultaneous measurement of metals allows us to obtain a stable ratio in their quantitative content, which is especially important when it is necessary to obtain results for several elements. Measurements were made at a $63 \mathrm{eV}$ current and a $45 \mathrm{kV}$ anode voltage. Spectrum was decoded by ElvaX software. Further statistical processing was performed using Microsoft Excel 2003 and SPSS 21.0 software. Statistical significance of differences between indices was evaluated by MannWhitney U test.

The studies were conducted within the frame of research of State Institution Institute for Occupational Health of NAMS of Ukraine: scientific substantiation of principles, methods and indicators for experimental evaluation of the toxicity of nanoparticles and nanomaterials of heavy metals (State registry number 0113U001447) and the characteristics of toxic effects of nanoparticles of heavy metals, search and scientific justification of preventive measures (State registry number 0116U00497).

\section{Results and discussion}

The results showed accumulation of cadmium and changes in the content of micro-and macro-elements 
in the liver (Table 1) and kidneys (Table 2) after a prolonged exposure to cadmium compounds in nanoand ion forms.

Cadmium content in the liver in the first study period after exposure to 4-6 nm CdS NP increased by 111 times, 9-11 nm CdS NP by 127 times, and $\mathrm{CdCl}_{2}$ by 172 times. In the second study period, there was no further accumulation of cadmium in the liver and its contents were not statistically different from those of the first period, which could be due to its redistribution in the body and gradual elimination. In the post-exposure period, the level of cadmium in the liver also increased significantly, in comparison with the previous periods of the study. Thus, the content of cadmium after exposure to 4-6 nm CdS NP increased by 387 times, those of $9-11 \mathrm{~nm}$ CdS NP by 261 times, $\mathrm{CdCl}_{2}$ by 461 times.

The content of calcium in the liver varied insignificantly. The statistically significant increase of its level was recorded in the first study period after exposure to $\mathrm{CdCl}_{2}$, and in the second period to CdS NP of both sizes. In the post-exposure period, statistically significant differences in the content of calcium in the liver between the experimental and control groups of animals were not detected.

The content of copper in the liver of all experimental groups in the three study periods was statistically significantly higher as compared to the control parameters, with the most intensive accumulation of copper, recorded in animals exposed to $\mathrm{CdCl}_{2}$ and smaller CdS NPs.

The iron content in the liver after 30 and 60 injections of all studied cadmium compounds was not statistically significantly different from the control parameters. In the post-exposure period, the increase in its level in animals exposed to $4-6 \mathrm{~nm}$ CdS NP was by 2,4 times, $9-11 \mathrm{~nm}$ CdS NP by $2-2$ times, and $\mathrm{CdCl}_{2}$ by 2 times.

An intensive increase in zinc levels in the liver of the exposed animals in all study periods was recorded, compared with the control group. The content of selenium after 30 and 60 injections of cadmium com-

The content of macro- and microelements in the liver of rats $(M \pm m), \mu \mathrm{g} / \mathrm{g}$

\begin{tabular}{|c|c|c|c|c|c|}
\hline \multirow{2}{*}{$\begin{array}{l}\text { Macro- and } \\
\text { microelement }\end{array}$} & \multirow{2}{*}{ Period } & \multirow{2}{*}{ Control group } & \multicolumn{3}{|c|}{ Experimental groups } \\
\hline & & & I - CdS 4-6 nm & II - CdS 9-11 nm & III $-\mathbf{C d C l}_{2}$ \\
\hline \multirow{3}{*}{ Cadmium } & 30 injections & $0,16 \pm 0,05$ & $17,78 \pm 1,25^{*}$ & $20,27 \pm 1,98^{*}$ & $27,53 \pm 12,70^{*}$ \\
\hline & 60 injections & $0,13 \pm 0,04$ & $18,03 \pm 0,37^{* \sim}$ & $25,19 \pm 2,16^{* \#}$ & $32,94 \pm 6,45^{*}$ \\
\hline & PEP & $0,14 \pm 0,04$ & $54,28 \pm 8,48^{*}$ & $36,63 \pm 1,51^{* \# \sim ~}$ & $64,60 \pm 3,25^{*}$ \\
\hline \multirow{3}{*}{ Calcium } & 30 injections & $88,56 \pm 28,46$ & $119,63 \pm 34,56^{\sim}$ & $59,28 \pm 12,53^{\sim \#}$ & $264,49 \pm 108,42 *$ \\
\hline & 60 injections & $74,21 \pm 24,10$ & $148,38 \pm 13,17^{* \sim}$ & $180,27 \pm 23,75^{* \sim}$ & $92,30 \pm 26,39$ \\
\hline & PEP & $77,05 \pm 24,76$ & $57,02 \pm 8,43^{\sim}$ & $119,22 \pm 16,49^{\#}$ & $130,86 \pm 27,90$ \\
\hline \multirow{3}{*}{ Copper } & 30 injections & $1,71 \pm 0,14$ & $2,76 \pm 0,10^{*}$ & $2,72 \pm 0,36^{*}$ & $3,26 \pm 1,42 *$ \\
\hline & 60 injections & $1,43 \pm 0,13$ & $2,27 \pm 0,10^{*}$ & $2,07 \pm 0,15^{*}$ & $1,92 \pm 0,35^{*}$ \\
\hline & PEP & $1,49 \pm 0,12$ & $2,86 \pm 0,46^{*}$ & $2,63 \pm 0,15^{* \sim}$ & $3,09 \pm 0,26^{*}$ \\
\hline \multirow{3}{*}{ Iron } & 30 injections & $34,83 \pm 1,63$ & $55,65 \pm 8,64^{*}$ & $55,16 \pm 15,95$ & $67,35 \pm 37,35$ \\
\hline & 60 injections & $29,57 \pm 1,34$ & $35,62 \pm 3,41$ & $32,65 \pm 3,81$ & $31,44 \pm 6,29$ \\
\hline & PEP & $30,30 \pm 1,42$ & $73,21 \pm 15,56^{*}$ & $66,57 \pm 6,65^{*}$ & $61,07 \pm 3,59^{*}$ \\
\hline \multirow{3}{*}{ Zinc } & 30 injections & $13,99 \pm 0,53$ & $30,25 \pm 1,98^{*}$ & $30,57 \pm 2,23^{*}$ & $39,20 \pm 15,64^{*}$ \\
\hline & 60 injections & $11,88 \pm 0,45$ & $24,57 \pm 2,38^{*}$ & $26,47 \pm 2,48^{*}$ & $28,85 \pm 5,54 *$ \\
\hline & PEP & $12,17 \pm 0,46$ & $33,01 \pm 4,53^{*}$ & $26,04 \pm 1,75^{*}$ & $30,89 \pm 1,38^{*}$ \\
\hline \multirow{3}{*}{ Selenium } & 30 injections & $2,35 \pm 0,64$ & $0,39 \pm 0,05^{*}$ & $0,49 \pm 0,05^{*}$ & $0,47 \pm 0,20^{*}$ \\
\hline & 60 injections & $1,96 \pm 0,54$ & $0,18 \pm 0,03^{*}$ & $0,23 \pm 0,03 *$ & $0,23 \pm 0,04 *$ \\
\hline & PEP & $2,05 \pm 0,56$ & $6,62 \pm 2,22^{* \sim}$ & $1,11 \pm 0,07^{* \#}$ & $1,21 \pm 0,07^{*}$ \\
\hline
\end{tabular}

Note. *Statistically significant difference in indices between exposed groups and the control group; "statistically significant difference between the groups of animals exposed to CdS NP of different size; - statistically significant difference between groups of animals exposed to $\mathrm{CdSNP}$ and $\mathrm{CdCl}_{2} ; \mathrm{p}<0,05$. PEP-post-exposure period. 
The content of macro- and microelements in the kidney of rats $(M \pm m), \mu g / g$

\begin{tabular}{|c|c|c|c|c|c|}
\hline \multirow{2}{*}{$\begin{array}{c}\text { Macro- and } \\
\text { microelement }\end{array}$} & \multirow{2}{*}{ Period } & \multirow{2}{*}{ Control group } & \multicolumn{3}{|c|}{ Experimental groups } \\
\hline & & & $\mathrm{I}-\mathrm{CdS}$ 4-6 nm & II - CdS 9-11 nm & $\mathrm{III}-\mathrm{CdCl}_{2}$ \\
\hline \multirow{3}{*}{ Cadmium } & 30 injections & $0,21 \pm 0,06$ & $30,75 \pm 2,15^{*}$ & $30,15 \pm 2,13^{* \sim}$ & $16,53 \pm 2,32 *$ \\
\hline & 60 injections & $0,30 \pm 0,04$ & $56,08 \pm 11,79^{*}$ & $71,72 \pm 4,69^{* \sim}$ & $57,95 \pm 6,90^{*}$ \\
\hline & PEP & $0,25 \pm 0,05$ & $81,37 \pm 2,52^{* \sim}$ & $72,10 \pm 2,30 * \# \sim$ & $53,37 \pm 4,09^{*}$ \\
\hline \multirow{3}{*}{ Calcium } & 30 injections & $12,11 \pm 20,87$ & $129,10 \pm 31,75$ & $124,44 \pm 14,52$ & $124,44 \pm 19,35$ \\
\hline & 60 injections & $149,0 \pm 25,25$ & $139,06 \pm 18,69$ & $151,74 \pm 20,07$ & $136,98 \pm 25,99$ \\
\hline & PEP & $116,51 \pm 20,24$ & $94,31 \pm 12,36$ & $92,73 \pm 14,48$ & $106,79 \pm 18,74$ \\
\hline \multirow{3}{*}{ Copper } & 30 injections & $2,73 \pm 0,30$ & $7,0 \pm 0,60 *$ & $7,42 \pm 0,59 *$ & $5,69 \pm 0,56^{*}$ \\
\hline & 60 injections & $3,34 \pm 0,37$ & $6,02 \pm 1,0^{*}$ & $7,45 \pm 0,52 *$ & $7,45 \pm 0,88^{*}$ \\
\hline & PEP & $2,65 \pm 0,29$ & $5,62 \pm 0,50^{*}$ & $4,50 \pm 0,40^{*}$ & $4,73 \pm 0,44^{*}$ \\
\hline \multirow{3}{*}{ Iron } & 30 injections & $23,96 \pm 3,68$ & $18,81 \pm 2,14$ & $18,72 \pm 0,88$ & $16,23 \pm 1,61$ \\
\hline & 60 injections & $29,73 \pm 4,13$ & $13,22 \pm 3,08^{*}$ & $12,73 \pm 0,86^{*}$ & $16,82 \pm 1,51^{*}$ \\
\hline & PEP & $23,24 \pm 3,57$ & $14,69 \pm 1,07 *$ & $14,44 \pm 0,98^{*}$ & $13,11 \pm 1,21^{*}$ \\
\hline \multirow{3}{*}{ Zinc } & 30 injections & $12,83 \pm 1,25$ & $15,34 \pm 0,94$ & $15,29 \pm 1,51$ & $12,17 \pm 0,36$ \\
\hline & 60 injections & $15,79 \pm 1,51$ & $12,02 \pm 1,66$ & $16,11 \pm 4,92$ & $15,81 \pm 1,48$ \\
\hline & PEP & $12,45 \pm 1,21$ & $15,71 \pm 0,80$ & $15,53 \pm 0,67$ & $11,84 \pm 0,58$ \\
\hline \multirow{3}{*}{ Selenium } & 30 injections & $2,04 \pm 0,23$ & $0,90 \pm 0,08^{*}$ & $1,04 \pm 0,16^{*}$ & $0,80 \pm 0,06^{*}$ \\
\hline & 60 injections & $2,49 \pm 0,28$ & $0,61 \pm 0,11^{*}$ & $2,08 \pm 1,53^{\sim}$ & $0,84 \pm 0,10^{*}$ \\
\hline & PEP & $1,98 \pm 0,22$ & $1,80 \pm 0,28^{\sim}$ & $1,49 \pm 0,05^{*}$ & $1,23 \pm 0,09^{*}$ \\
\hline
\end{tabular}

Note. *Statistically significant difference in indices between exposed groups and the control group; ${ }^{*}$ statistically significant difference between the groups of animals exposed to CdS NP of different size; statistically significant difference between groups of animals exposed to $\mathrm{CdSNP}$ and $\mathrm{CdCl}_{2} ; p<0,05$. PEP-post-exposure period.

pounds was statistically significantly lower, compared with the control group. In the post-exposure period, its content increased, compared with the second period, however, in rats exposed to 9-11 nm CdS NP and $\mathrm{CdCl}_{2}$, it was statistically significantly lower than the control values.

Thus, in the liver of rats exposed to $\mathrm{CdCl}_{2}$ and $\mathrm{CdS}$ $\mathrm{NP}$ there was recorded the intensive accumulation of cadmium, increase in the content of copper, iron and zinc, as well as the decrease in selenium content, indicating the occurrence of a trace elemental imbalance, which may play an important role in the pathogenesis of cadmium hepatotoxic action.

A significant accumulation of cadmium content was recorded in the kidneys in all studied periods. In particular, after 30 injections of CdS NP of 4,65 nm the cadmium content increased 146 times, with CdS NP of $10,08 \mathrm{~nm}$ it increased in 143 times, with $\mathrm{CdCl}_{2}-$ in 79 times; and after 60 injections in 187, 239 and 193 times, respectively; while in the post-exposure period in 325, 288 and 213 times, respectively. Thus, the smallest cadmium content among experimental groups was recorded under the exposure to $\mathrm{CdCl}_{2}$. This can be explained by the fact that animals of this group most actively accumulated cadmium in the liver, aorta, heart and brain, resulting in a more slowly excretion from the body and in less reabsorption by proximal tubules of the kidneys (unpublished data).

In the kidneys of rats no substantial statistically significant differences in the content of calcium and zinc were detected in all studied periods, compared with the corresponding control parameters. The content of copper was statistically significantly higher in rats of all three experimental groups in all studied periods, indicating the accumulation of copper in the kidneys in exposure conditions with cadmium compounds. A statistically significant decrease in the iron content, compared with the control values, was recorded in rat kidneys after 60 injections of $\mathrm{CdS} \mathrm{NP}$ and $\mathrm{CdCl}_{2}$, and in the post-exposure period. The content of selenium in 
the first and second observation periods was statistically significantly lower than the control levels, and in the post-exposure period its statistically significant decrease was recorded in rats with the $\mathrm{CdCl}_{2}$ intake.

Thus, in the kidney of rats, exposed to $\mathrm{CdCl}_{2}$ and $\mathrm{CdS} \mathrm{NP}$, an intensive accumulation of cadmium was recorded, as well as a trace elements imbalance when the copper content increased and the content of iron and selenium decreased.

Summarizing the results we can draw the following conclusions:

Determination of the content of cadmium, macroand microelements in inner organs allows to evaluate cadmium toxicokinetics in the body, to predict pathogenetic features of its toxic effects, especially in the post-exposure period, as well as to study the peculiarities of the pathogenesis of its organotoxic action.

In the liver cadmium was most intensively accumulated after exposure to $\mathrm{CdCl}_{2}$, especially in the

\section{References}

1. Liu, L., Sun, M., Li, Q. et al. 2014, «Genotoxicity and Cytotoxicity of Cadmium Sulfide Nanomaterials to Mice: Comparison Between Nanorods and Nanodots", Environmental Engineering Science, v. 31 (7), pp. 373380.

2. Kozhevnikova, N.,S., Vorokh, A.,S., Uritskaya, A.,A.2015, "Cadmium sulfide nanoparticles prepared by chemical bath deposition", Russian Chemical Reviews, v. 84 (3), pp. 225-250 (in Russian).

3. Jarup, L., Berglund, M., Elinder, C. et al. 1998, "Health effects of cadmium exposure - a review of the literature and a risk estimate", Scandinavian Journal of Work, Environment \& Health, v. 1, pp. 1-52.

4. Godt, J., Scheidig, F., Grosse-Siestrup, C. et al. 2006, "The toxicity of cadmium and resulting hazards for human health", Journal of Occupational Medicine and Toxicology, v. 1, pp. 22-28, doi: 10.1186/1745-6673-1-22.

5. Åkesson, A., Barregard, L., Bergdahl, I. A. et al. 2014, "Non-renal effects and the risk assessment of environmental cadmium exposure", Environmental Health Perspectives, v. 122 (5), p. 431-438.

6. Jie, Liu, Wei, Qu, Kadiiska, M. B. 2009, "Role of oxidative stress in cadmium toxicity and carcinogenesis",

\section{Апихтіна О. А., Козлов К. П.}

BMICT MIKPO- I MAKPOEAEMEHTIB Y ПEЧIHUI TA HИPКАХ UYPIB ПIC ЕКСПОЗИUÏ ХАОРИАОМ КААМІЮ ТА НАНОЧАСТИНКАМИ СУАЬФІАУ КААМІЮ

Аержавна установа «Інститут меАицини праці Нашіональної академії медичних наук України», м. Київ

Bcmyn. Упровадження наночастинок (НЧ) сполук кадмію у виробництво обумовлює необхідність вивчення механізму їхньої дії як на клітинному рівні, так і на рівні органів і систем, визначення біомаркерів їхнього впливу, особливо порівняно з іонною формою. post-exposure period. Higher cadmium content was observed after exposure to 4-6 nm CdS NP, compared with 9-11 nm CdS NP. Along with the increase in cadmium content in the liver, the increase in the content of copper, iron (more intensively after $\mathrm{CdCl}_{2}$ exposure), iron, and decreased selenium levels (especially after 4-6 nm CdS NP exposure) was found.

Significant accumulation of cadmium was recorded in the kidneys, especially in the post-exposure period, which may indicate on intensive limination from the body. The prolonged exposure to cadmium compounds also led to the increase in copper levels and decrease in iron and selenium levels in the kidneys. The most significant changes were recorded after the exposure to CdS NP, especially of 4-6 nm size, compared with $\mathrm{CdCl}_{2}$.

Intensive accumulation of cadmium and imbalance of trace elements can play a leading role in the development of hepatotoxic and nephrotoxic effects of cadmium compounds in nano- and ionic form.

Toxicology and Applied Pharmacology, v. 238 (3) pp. 209-214.

7. Huff, J., Lunn, R. M., Waalkes, M. P. et al. 2007, "Cadmium-induced Cancers in Animals and in Humans", InternationalJournal of Occupational and Environmental Health, v. 13 (2), pp. 202-212.

8. Adams, S. V., Passarelli, M. N., Newcomb, P. A. 2012, "Cadmium exposure and cancer mortality in the Third National Health and Nutrition Examination Survey cohort", Occupational and Environmental Medicine, v. 69 (2), pp. 153-156.

9. Prozialeck, W. C., Edwards, J. R. 2010, "Early biomarkers of cadmium exposure and nephrotoxicity", Biometals, v. 23 (5), pp. 793-809. doi: 10.1007/s10534010-9288-2.

10. He, L., Wang, B., Hay, E. B., Nebert. D. W. 2009, "Discovery of ZIP transporters that participate in cadmium damage to testis and kidney", Toxicology and Applied Pharmacology, v. 238, pp. 250-257.

11. Prozialeck, W. C., Edwards, J. R. 2012, "Mechanisms of Cadmium-Induced Proximal Tubule Injury: New Insights with Implications for Biomonitoring and Therapeutic Interventions", Journal of Pharmacology and Experimental Therapeutics, v. 343 (1), pp. 2-12. doi: 10.1124/jpet.110.166769. 
Мета дослідження - порівняльна оцінка вмісту мікро- та макроелементів у печінці та нирках дослідних тварин після експозиції хлоридом кадмію та НЧ сульфіду кадмію.

Матеріали та методи дослідження. Дослідження проводили на щурах-самцях статевозрілого віку лінії Вістар вагою 160-180 г, яким внутрішньоочеревинно вводили $\mathrm{CdCl}_{2}$ та $\mathrm{CdS}$ NP розміром 4-6 nm та 9-11 nm та в дозі 0,08 мг/кг/ добу в перерахунку на кадмій. Токсичні ефекти оцінювали після 30 injections $(1,5$ міс.), 60 injections (3,0 міс.) та через 1,5 міс. після припинення експозиціі.

Результати. У печінці дослідних тварин найінтенсивніше накопичувався кадмій після експозиції СdСl 2 , особливо в постекспозиційному періоді. Спостерігали більш високий вміст кадмію за дії CdS NP розміром 4-6 nm, comparing to CdS NP розміром 9-11 nm. Поряд зі зростанням вмісту кадмію в печінці реєстрували зростання вмісту міді, заліза (більш інтенсивно за дії $\mathrm{CdCl}_{2}$ ), заліза та зниження рівня селену (особливо за дії CdS NP розміром 4-6 nm). У нирках реєстрували значне накопичення кадмію, особливо в постекспозиційному періоді, що може свідчити про його інтенсивне виведення з організму. Тривала експозиція сполуками кадмію спричиняла також зростання рівня міді та зниження заліза й селену в нирках. Найсуттєвіші зміни реєстрували після експозиціï CdS NP, especially of 4-6 nm in size, comparing to $\mathrm{CdCl}_{2}$. Інтенсивне накопичення кадмію та дисбаланс мікроелементів може відігравати провідну роль у реалізації гепато- та нефротоксичної дії сполук кадмію в нано- та іонній формі.

Висновки. Визначення вмісту кадмію, макро- і мікроелементів у внутрішніх органах дозволяє оцінити особливості токсикокінети цього металу в організмі, передбачити патогенетичні особливості реалізації його токсичних ефектів, особливо в постекспозиційному періоді, а також дослідити особливості патогенезу його органотоксичної дії.

Ключові слова: кадмій, наночастинки, печінка, нирки, цинк, селен, мідь, залізо, кальцій

Апыхтина Е. А., Козлов К. П.

\section{СОАЕРХКАНИЕ МИКРО- И МАКРОЭАЕМЕНТОВ В ПЕЧЕНИ И ПОЧКАХ КРЫС ПОСАЕ ЭКСПОЗИЧИИ ХАОРИАОМ КААМИЯ И НАНОЧАСТИЧ СУАЬФИАА КААMИЯ}

Государственное учрежАение «Институт медишины труда Нашиональной академии медицинских наук Украины», г. Киев

Введение. Внедрение наночастиц (НЧ) соединений кадмия в производство обусловливает необходимость изучения механизма их действия как на клеточном уровне, так и на уровне органов и систем, определения биомаркеров их влияния, особенно по сравнению с ионной формой.

Цель исследования - сравнительная оценка содержания микро- и макроэлементов в печени и почках экспериментальных животных после экспозиции хлоридом кадмия и НЧ сульфида кадмия.

Материалы и методы исследования. Исследования проводили на крысах-самцах половозрелого возраста линии Вистар весом 160-180 г, которым внутрибрюшинно вводили $\mathrm{CdCl}_{2}$ и $\mathrm{CdS}$ NP размером 4-6 nm и 9-11 nm в дозе 0,08 мг/кг/сут в пересчете на кадмий. Токсические эффекты оценивали после 30 введений (1,5 мес.), 60 вводов (3,0 мес.) и через 1,5 мес. после прекращения экспозиции.

Результаты. В печени экспериментальных животных наиболее интенсивно накапливался кадмий после экспозиции $\mathrm{CdCl}_{2}$, особенно в постэкспозиционном периоде. Наблюдали более высокое содержание кадмия при воздействии CdS NP размером 4-6 nm, по сравнению с CdS NP размером 9-11 nm. Наряду с ростом содержания кадмия в печени регистрировали повышение содержания меди, железа (более интенсивно при воздействии СdCl ${ }_{2}$ ), железа и снижение уровня селена (особенно при воздействии CdS NP размером 4-6 nm). В почках регистрировали значительное накопление кадмия, особенно в постэкспозиционном периоде, что может свидетельствовать о его интенсивном выведении из организма. Длительная экспозиция соединениями кадмия вызывала также рост уровня меди, снижение железа и селена в почках. Наиболее существенные изменения регистрировали после экспозиции CdS NP, особенно размером 4-6 nm, по сравнению с $\mathrm{CdCl}_{2}$. Интенсивное накопление кадмия и дисбаланс микроэлементов может играть ведущую роль в реализации гепато- и нефротоксического действия соединений кадмия в нано- и ионной форме.

Bbводы. Определение содержания кадмия, макро- и микроэлементов во внутренних органах позволяет оценить особенности токсикокинетики этого металла в организме, предусмотреть патогенетические особенности реализации его токсических эффектов, особенно в постэкспозиционном периоде, а также исследовать особенности патогенеза его органотоксичного воздействия.

Ключевые слова: кадмий, наночастицы, печень, почки, цинк, селен, медь, железо, кальций 


\section{Література}

1. Genotoxicity and Cytotoxicity of Cadmium Sulfide Nanomaterials to Mice: Comparison Between Nanorods and Nanodots / L. Liu, M. Sun, Q. Li [et al.] // Environmental Engineering Science. - 2014. - V. 31 (7). P. 373-380.

2. Cadmium sulfide nanoparticles prepared by chemical bath deposition / N. S. Kozhevnikova, A. S. Vorokh, A .A. Uritskaya // Russian Chemical Reviews. - 2015. V. 84 (3). - P. 225-250.

3. Health effects of cadmium exposure - a review of the literature and a risk estimate / L. Jarup, M. Berglund, C. Elinder [et al.] // Scandinavian Journal of Work, Environment \& Health. - 1998. - V. 1. - P. 1-52.

4. The toxicity of cadmium and resulting hazards for human health / J. Godt, F. Scheidig, C. Grosse-Siestrup [et al.] // Journal of Occupational Medicine and Toxicology. - 2006. - V. 1. - P. 22-28.

5. Non-renal effects and the risk assessment of environmental cadmium exposure / A. Åkesson, L. Barregard, I. A. Bergdahl [et al.] // Environmental Health Perspectives. - 2014. - V. 122 (5). - P. 431-438.

6. Jie Liu. Role of oxidative stress in cadmium toxicity and carcinogenesis / Liu Jie, Qu Wei, M. B. Kadiiska //
Toxicology and Applied Pharmacology. - 2009. - V. 238 (3). - P. 209-214.

7. Cadmium-induced Cancers in Animals and in Humans / J. Huff, R. M. Lunn, M. P. Waalkes [et al.] // InternationalJournal of Occupationaland Environmental Health. - 2007. - V. 13 (2), pp. 202-212.

8. Adams S. V. Cadmium exposure and cancer mortality in the Third National Health and Nutrition Examination Survey cohort / S. V. Adams, M. N. Passarelli, P. A. Newcomb // Occupational and Environmental Medicine. - 2012. - V. 69 (2). - P. 153-156.

9. Prozialeck W. C. Early biomarkers of cadmium exposure and nephrotoxicity / / W. C. Prozialeck, J. R. Edwards / / Biometals. - 2010. - V. 23 (5). - P. 793-809.

10. Discovery of ZIP transporters that participate in cadmium damage to testis and kidney / L. He, B. Wang, E. B. Hay, D. W. Nebert / / Toxicology and Applied Pharmacology. - 2009. - V. 238. - P. 250-257.

11. Prozialeck W. C. Mechanisms of CadmiumInduced Proximal Tubule Injury: New Insights with Implications for Biomonitoring and Therapeutic Interventions / W. C. Prozialeck, J. R. Edwards // Journal of Pharmacology and Experimental Therapeutics. - 2012. V. 343 (1). - P. 2-12.

\section{Надійшла: 7 червня 2017 р.}

Контактна особа: Апихтіна Олена Леонідівна, кандидат медичних наук, лабораторія промислової токсикології та гігієни праці при використанні хімічних речовин, ДУ «Інститут медицини праці НАМН України», буд. 75, вул. Саксаганського, м. Київ, 01033. Тел.: + 3804428951 85. Електронна пошта: ol_apyht@ukr.net 